\title{
Article
}

\section{Conflict Resolution in Post-violence Societies: Some Guidance for the Judiciary}

\author{
Hadjigeorgiou, Athanasia
}

Available at http://clok.uclan.ac.uk/33969/

Hadjigeorgiou, Athanasia ORCID: 0000-0002-7324-9689 (2021) Conflict

Resolution in Post-violence Societies: Some Guidance for the Judiciary. The International Journal of Human Rights, 25 (4). pp. 695-717. ISSN 1364-2987

It is advisable to refer to the publisher's version if you intend to cite from the work. http://dx.doi.org/10.1080/13642987.2020.1791827

For more information about UCLan's research in this area go to http://www.uclan.ac.uk/researchgroups/ and search for < name of research Group>.

For information about Research generally at UCLan please go to http://www.uclan.ac.uk/research/

All outputs in CLoK are protected by Intellectual Property Rights law, including Copyright law. Copyright, IPR and Moral Rights for the works on this site are retained by the individual authors and/or other copyright owners. Terms and conditions for use of this material are defined in the policies page.

\section{CLoK}

Central Lancashire online Knowledge www.clok.uclan.ac.uk

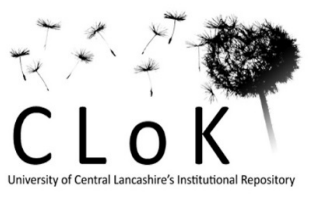




\title{
Conflict Resolution in Post-violence Societies: Some Guidance for the Judiciary
}

\begin{abstract}
The article is concerned with a worldwide phenomenon that is particularly prevalent in postviolence societies, whereby conflicts that should have been resolved in the political arena, are adjudicated by the judiciary. It offers reasons for this phenomenon and argues that when judges face this task, they tend to base their reasoning on human rights arguments. While convenient, using human rights as proxies for a more complex political analysis can undermine the quality of both the judgment and remedies provided by the court. Alternatively, when courts adjudicate political conflicts, they should rely on constitutional guiding principles. Their main advantage is that they expressly acknowledge the political and controversial nature of the conflicts at hand, thus result in a more transparent reasoning. Additionally, their more flexible nature makes constitutional principles applicable to a broader range of conflicts and can result in more appropriate remedies upon their adjudication.
\end{abstract}

Key words: Political conflicts, judiciary, human rights, constitutional principles.

\section{Author: Nasia Hadjigeorgiou}

\section{A. Introduction}

In 2002 the South African Constitutional Court was faced with one of the most divisive political questions in the country. It was asked to decide whether someone who had been elected to Parliament as a member of one political party could, during the same parliamentary session, become a member of another party while keeping his seat in the legislature. ${ }^{1}$ In answering this question, the Court made it clear that

This case is not about the merits or demerits of the provisions of the disputed legislation. That is a political question and is of no concern to this Court. What has to 
be decided is not whether the disputed provisions are appropriate or inappropriate, but whether they are constitutional or unconstitutional. ${ }^{2}$

Having made this not-entirely persuasive distinction, the Court, relying on the right to political participation protected under Section 19 of the Constitution, upheld the disputed provisions and allowed the practice of floor-crossing. This case exemplifies an increasing expectation from the South African Constitutional Court to adjudicate political conflicts, which often go to the heart of democratic politics in the country. At the same time, the floor-crossing case illustrates a tendency of the Court to resolve such conflicts by relying on human rights arguments. Neither of the two tendencies is a South Africa-specific phenomenon. Rather, over the last generation, political conflicts have increasingly become questions of constitutional law throughout the world. The adjudication of political conflicts by apex courts has been observed by Hirschl in New Zealand, Canada, Israel and South Africa; ${ }^{3}$ by Tierney in Canada, Spain and the $\mathrm{UK} ;{ }^{4}$ by Issacharoff and Pildes, ${ }^{5}$ and Ferejohn in the US $;{ }^{6}$ by Feldman in Bosnia and Herzegovina $;{ }^{7}$ and by Anthony and Morison in Northern Ireland. ${ }^{8}$

While the resolution of political conflicts by the judiciary is a worldwide phenomenon, it is particularly prevalent in post-violence societies. Section 2 of this article explains what is meant by the terms 'post-violence societies' and 'political conflicts', and offers reasons for why courts in the former have played such a key role in the resolution of the latter. It argues that whatever theoretical arguments might exist in favour of or against greater judicial activism, in practice the tendency of apex courts to adjudicate political conflicts is becoming more and more popular. With this starting point in mind, Section 3 gives reasons for the second phenomenon illustrated by the floor-crossing case, namely that when courts do get involved in the resolution of such conflicts, they often base their reasoning on human rights arguments. While convenient, this type of judicial reasoning should be avoided because viewing human rights as proxies for 
more complex political arguments can undermine the quality of both the judgment and remedies provided by the court. Considering these difficulties, Section 4 proposes that when courts adjudicate political conflicts, they should rely on constitutional guiding principles, such as democracy, which are to be interpreted in light of each society's history and context. The main advantage of these principles, which should be used either instead of human rights or as complementary to them, is that they acknowledge the political and controversial nature of the conflicts the courts have been asked to adjudicate. Due to this, their use results in more transparent reasoning, which offers guidance for the resolution of the conflict at hand and for any other future ones that might arise. Finally, constitutional guiding principles are more flexible than human rights, in terms of the political conflicts to which they apply and the types of remedies they might give rise to.

\section{B. Explaining the Judiciary's Involvement in Political Conflicts}

Political conflicts in post-violence societies are concerned with issues that were drivers in the eruption of violence in the first place and are therefore, also of central importance during the transitionary period to peace. ${ }^{9}$ For example, if the society in question was divided and fought a war along ethnic lines, a political conflict in the aftermath of the peace agreement would concern questions of how different ethnic groups could be protected. Such questions could focus on safeguarding the language or religion of the ethnic group, or on how the group could secure its political or economic power within the new state of affairs. ${ }^{10}$ Conflicts about political power often centre around the organising of elections and the procedures to be used when passing new legislation, while disagreements about economic power might have to do with hiring practices and the use of ethnic quotas in state institutions. Examples of these conflicts are referred to through the article. 
Most political conflicts will require the court to interpret either the peace agreement itself, or a constitutional document that has been drafted as a result of this agreement. Because they are by their nature controversial and divisive, these conflicts are likely to find their way to, and be adjudicated by, the apex courts of post-violence societies. The use of constitutional principles advocated here applies equally to both types of apex courts, but for reasons discussed later, it is likely that they will be used more by constitutional courts, compared to supreme ones. The article only makes the case for relying on constitutional principles during the adjudication of political cases in post-violence societies. Whether this would be a prudent strategy to use more broadly - for example, for different types of cases or in other types of societies - should be the subject of further research. ${ }^{11}$

Political conflicts are often presented in legal terms, but their answers are not only (or even primarily) dependent on a deep knowledge of the law or sound legal reasoning; to put it differently, the outcome of political conflicts is by no means a legal certainty. ${ }^{12}$ Thus, the question of whether floor-crossing should be allowed is more appropriately answered by taking into account the likely effect of this practice on political parties, the striking of political deals and the way in which it will affect people's perceptions of democracy. Despite the South African Court's insistence to the contrary, it is these political factors, rather than any legal considerations, that mostly determine whether floor-crossing should be allowed or not. ${ }^{13}$

The rest of this article will use a range of cases as non-exhaustive illustrations of political conflicts. These include the adjudication of disputes relating to ethnic representation in state institutions, amnesty powers of Truth and Reconciliation Commissions, the democratic processes that should be adopted when passing controversial legislation and questions of whether a ceasefire agreement has been breached. Despite the very different subject matters of 
these cases, they are all representative of political conflicts because they are concerned with disagreements that go to the heart of the transition process in the country. What makes them noteworthy is not that they involve the interpretation of the peace agreement, an exercise that can be, but is not always controversial or politically charged. Rather, they have been selected as representative examples of political conflicts because a failure to resolve them risks delegitimising the peace process or further polarising groups that had previously resorted to violence. In this respect, a dispute being elevated to a political conflict in one country, will not necessarily suffer the same fate in another; whether this will happen, depends on the divisiveness of the question at hand in that particular context.

The expectation that courts will adjudicate and resolve political conflicts is particularly prevalent, and has even greater practical effects, in societies that are emerging from violent conflict. ${ }^{14}$ Such transitions from violence to a more peaceful state of affairs, often involve the adoption of a negotiated peace agreement between the previously warring parties and almost always result in significant political changes to the country. The societies that are undergoing these transitions are frequently labelled in the literature as 'post-conflict', a term which implies that conflicts are necessarily violent phenomena that are best eliminated. ${ }^{15}$ However, political conflicts exist in every healthy democratic society and the objective should not be to eliminate them, an outcome that would be both undesirable and arguably impossible to achieve, but to ensure that they are resolved so that they do not turn violent. ${ }^{16}$ One way of achieving this is through the political process, whereby policy makers debate and decide on the best way to resolve conflicts, and another - which is the focus of this article - is to adjudicate them in a court of law. ${ }^{17}$ 
Having rejected the 'post-conflict' label, this article will use instead, the term 'post-violence society' to encapsulate those social formations that have undergone a transition from communal violence to relative non-violence, but naturally, remain divided by a range of political conflicts. ${ }^{18}$ Such societies might vary considerably between themselves in terms of the history, scale or nature of the violence they experienced. Examples include Bosnia and Herzegovina, which emerged from a 3-year war among its three main ethnic groups; ${ }^{19}$ South Africa, characterised by intense violence, although not an all-out war, both during apartheid and the period leading to the first democratic election; ${ }^{20}$ and Northern Ireland, where the violence during the Troubles lasted from the late 1960 s to $1998 .^{21}$ Despite their differences, post-violence societies are also faced with similar challenges and dilemmas. ${ }^{22}$ At their most fundamental, these dilemmas are concerned with the post-violence transition itself: how best to deal with the society's violent past and avoid its repetition by planning for the future. ${ }^{23}$ Despite their political nature, in post-violence contexts, such dilemmas have often been addressed by the judiciary. Thus, the Bosnian Constitutional Court has decided on provisions relating to ethnic representation in state institutions, ${ }^{24}$ the South African Constitutional Court has determined the legality of the amnesty powers of the Truth and Reconciliation Commission; ${ }^{25}$ and the UK Appellate Committee of the House of Lords has ruled on the legality of the elections of the First Minister and First Deputy Minister in Northern Ireland. ${ }^{26}$ As Issacharoff has put it, 'simply as a descriptive matter, courts now routinely engage the complicated world of political power in ways unimaginable a few generations back. ${ }^{27}$

The objective of this article is not to assess the desirability, or otherwise, of this tendency. ${ }^{28}$ Rather, it is to explain its occurrence in post-violence societies by offering two reasons for the increasing adjudication of political conflicts: the first concerns the political situation that prevails in these countries, which often leaves members of the executive and legislature unable 
or unwilling to resolve the conflict at hand. The second, focuses on the adoption of constitutional documents and structures that, either explicitly or implicitly, push courts to play a more active role in the resolution of political dilemmas. Especially when the two factors coexist, judges are more likely to adopt an activist approach. ${ }^{29}$

The most obvious reason for the increased adjudication of such conflicts, is that post-violence societies are in the process of undergoing significant political changes. ${ }^{30}$ These, especially when controversial, can lead to fundamental disagreements between the political parties and leave them unable to reach a decision. ${ }^{31}$ When the political branches of the state are paralysed because of such disagreements, the task of decision-making falls on the shoulders of other institutions, such as the judiciary. ${ }^{32}$ Illustrative of this is case law from the Supreme Court of Cyprus, in which the judges originally refused to adjudicate a case concerning the state's obligations to investigate disappearances that had occurred during a period of inter-ethnic violence on the island, and asked the executive to engage in political negotiations for the successful resolution of the conflict. ${ }^{33}$ A few years later, and with the political negotiations still not yielding results, the Cypriot judiciary found a similar case admissible and resolved the conflict by clarifying the content of the state's obligations to locate and identify the missing persons' remains. ${ }^{34}$

The politicians' unwillingness to resolve such divisive conflicts is often institutionalised in societies that have adopted consociational systems of government. ${ }^{35}$ Consociationalism is a system of power-sharing among political elites that is designed to ensure cooperation between different ethnic groups in post-violence societies. ${ }^{36}$ However, the characteristics of consociational systems, and in particular their tendency to give to representatives of different ethnic groups the veto power, often result in stagnation of the political process and an inability 
to reach decisions. ${ }^{37}$ While advocates of consociationalism had originally failed to appreciate the significance of a strong judiciary, the need to address and avoid these political dead ends, has made courts in post-violence societies among the most relied on institutions. ${ }^{38}$ It is in light of these developments and expectations that the Bosnian Constitutional Court asserted the important role it would play in the resolution of political conflicts in the country and stated that, it:

as the supreme state court and guardian of the [consociational] Constitution of Bosnia and Herzegovina (Article VI.3), should have the role of assisting in de-blocking of the work of the Parliamentary Assembly of Bosnia and Herzegovina by its decision on the merits, if the Parliamentary Assembly is not capable of overcoming the problem by itself. $^{39}$

An additional factor that contributes to increased judicial activism in post-violence societies is the adoption of new constitutional documents that push in this direction. Such documents can be 'true' constitutions such as the one adopted in South Africa at the end of apartheid ${ }^{40}$ or in Bosnia, with the signing of the Dayton Peace Agreement. ${ }^{41}$ Alternatively, they might be an Act of Parliament, like the Northern Ireland Act 1998, which was enacted 'for the purpose of implementing the agreement reached at multi-party talks on Northern Ireland' ${ }^{42}$ The elevated importance of the 1998 Act, as being something more than an ordinary statute, has been recognised by the UK House of Lords, which declared that it 'is in effect a constitution'. ${ }^{43}$ Such constitutional documents tend to explicitly provide for the adjudication of political conflicts, either when the elected representatives cannot reach a decision themselves or during moments of great historical importance. 
One example of the former is Article IV(3)(f) of the Bosnian Constitution, which provides that the power to veto legislation can be used by delegates of each of the three main ethnic groups in the country when the relevant law has been 'declared to be destructive of a vital interest of the Bosniac, Croat, or Serb people'. If the delegates of at least one of the other two groups disagree with the use of the veto power, the dispute is resolved by the Constitutional Court. Such conflicts revolve around the most controversial political debates in the country - hence the reason they attracted the use of the veto in the first place - yet it is the unelected judiciary that is expected to resolve them. ${ }^{44}$ Thus, relying on this Article, the Court has adjudicated political conflicts, concerned with the language of operation and structure of the Public Broadcasting System of Bosnia and Herzegovina; ${ }^{45}$ and, with whether the languages of all the previously warring parties to the conflict should necessarily be taught in all higher education institutions. $^{46}$

On the other hand, Section 71(2) of the South African Interim Constitution provides an example of the second way in which post-violence constitutions explicitly empower judges, namely by mandating judicial intervention during an important moment in the country's history. Section 71(2) stated that the Final Constitution of South Africa would only come into force when 'the Constitutional Court has certified that all the provisions of such text comply with the Constitutional Principles'. This gave effect to an earlier political agreement between the African National Congress and the National Party, which provided that South Africa's transition to democracy would be a two-stage process. The first stage would involve the negotiation of an Interim Constitution and a set of constitutional principles. During the second stage, the members of the Constitutional Assembly, who were elected after the Interim Constitution came into effect, would negotiate a Final Constitution, which had to comply with the constitutional principles that had been identified at the beginning of the transition process. ${ }^{47}$ 
Thus, through Section 71(2), the judiciary became a major actor in the biggest political debate in the history of South Africa, since it was called to approve - or otherwise - the content of the Constitution itself. In other words, the Court did not only base its legitimacy on the Constitution, as it usually happens, but also, the Constitution derived its legitimacy from the Court's decision. Confirming that this was more than a mere rubber-stamping exercise, the Court ruled that several of the Final Constitution's provisions did not comply with the constitutional principles. ${ }^{48}$ This resulted in the resumption of political negotiations and, following their conclusion, a second certification case. ${ }^{49}$ Despite the unusually high level of judicial intervention in such a politically sensitive debate, the success of this two-stage process has led academics to propose its adoption in other post-violence societies as well. ${ }^{50}$

In addition to the constitutional provisions that explicitly call for greater judicial involvement when addressing political conflicts, the adoption of new constitutions in post-violence societies can have this effect in more indirect ways as well. For example, increased judicial activism is a possible consequence in societies where the constitution provides for the existence of a new constitutional court. These specialised judicial bodies have been popular in societies that emerged from violence from the 1990s onwards, as evidenced by their launch in places as diverse as South Africa in $1994,{ }^{51}$ East Timor in $2002^{52}$ and a future United Cyprus in case a peace agreement is reached. ${ }^{53} \mathrm{~A}$ more general tendency in this direction is also illustrated by the fact that while in $1978,26 \%$ of Constitutions provided for a Constitutional Court, this number increased to $44 \%$ by $2005 .{ }^{54}$ Studies suggest that all things being equal, the existence of a special constitutional court in the country, as opposed to a Supreme Court that also hears a range of other cases, is more likely to result in an activist judicial approach and less deferential standards of judicial review. ${ }^{55}$ Due to the nature of the case law that is usually before them, constitutional courts are more used to hearing and intervening in cases with significant 
political implications than the rest of the judiciary. Moreover, if constitutional courts refuse to hear such cases or simply always rubberstamp the government's position without engaging in serious review, they would be raising questions about the usefulness of their existence in the first place, something which judges are, naturally, keen to avoid.

The final factor that has indirectly increased the adjudication of political conflicts in postviolence societies is the fact that over the last decades, a 'rights revolution' has taken place, with newly enacted constitutions incorporating robust and extensive Bills of Rights. ${ }^{56}$ For example, the Bosnian Constitution makes the country a member to 16 international human rights treaties,${ }^{57}$ while the South African Constitution protects an array of civil, political, socioeconomic, cultural and group rights. ${ }^{58}$ Even older democracies have moved in this direction, with Canada adopting the Charter of Rights and Freedoms in 1982 and the UK Parliament passing the Human Rights Act in 1998. Such documents have made rights claims 'an increasing staple in the diets of the world's judiciary' and empowered judges to adjudicate a wider range of cases, some with important political implications. ${ }^{59}$ Illustrative of this was the use of two rights - freedom of religion and freedom from discrimination - to contest the introduction of positive discrimination measures, including quotas, when hiring for the Police Service of Northern Ireland. ${ }^{60}$ This challenge, while at its face a simple human rights case, went to the heart of seminal themes of the Northern Irish conflict, such as lack of security, mistrust of state institutions and discrimination in the workplace resulting in socio-economic inequalities. ${ }^{61}$ Thus, the introduction of Bills of Rights or other human rights instruments, similarly to the creation of specialised constitutional courts, while not necessarily intended to encourage the adjudication of political conflicts, has had this effect in practice. Whether one applauds or opposes this state of affairs, the factors discussed above have resulted in a growing expectation that the judiciary will be an important decision-maker in political dilemmas. ${ }^{62}$ Therefore, the 
question of what legal tools the courts should be relying on during this process is a matter of practical importance.

\section{Using Human Rights as Proxies}

In some cases where judges were called to adjudicate political conflicts, they have been careful to make reference to the political nature of the case in question. For example, when the Northern Ireland Court of Appeal was asked to determine whether the Provisional Irish Republican Army was 'maintaining a complete and unequivocal ceasefire' ${ }^{63}$ after the signing of the Belfast Agreement, it explicitly acknowledged that this was no ordinary case since it had significant political implications. ${ }^{64}$ Alternatively, there are cases, like those dealing with abortion, capital punishment or prisoner disenfranchisement, that are politically controversial (although do not fall within the definition of a 'political conflict' used here) and at the same time, only concerned with a narrow human rights issue that goes to the heart of the disagreement in question. In these cases, it is both natural and desirable that, rather than referring to the political nature of the case in question, the court adopts a human rights reasoning and derives inspiration from other domestic or international human rights judgments.

For most adjudicated political conflicts however, the disagreement in question is broader and more complex than what the human rights arguments relating to it portray it to be. Yet, both the parties and the judiciary tend to brush aside the political nature of the conflict and present it as a 'simple' human rights issue instead. ${ }^{65}$ Illustrative of this are a series of Bosnian cases, which challenged constitutional provisions that divided the seats in the legislature only among Bosniacs, Serbs and Croats and prevented Bosnians of other ethnicities, such as Jewish or Roma citizens, from running for office. ${ }^{66}$ Clearly, this complaint has a human rights dimension: by guaranteeing all the legislative seats to three ethnic groups, individuals who do not belong 
to one of these are discriminated against and prevented from exercising their right to be elected in the Parliamentary Assembly. ${ }^{67}$ At the same time however, the decision of how a country is going to design its legislature has much broader political implications than the disenfranchisement of an individual or even a group of individuals. ${ }^{68}$ Especially in postviolence contexts, it determines the kind of (new or reformed) democratic institutions that will operate in the country and the extent to which different political players are willing to cooperate between themselves in order to make them work. Such a debate therefore, is concerned not only with the relationship of individuals with the state, which human rights are designed to address, but also with questions concerning the structure of government as a whole, which they are not.

One explanation for the increased use of human rights as proxies in such cases is their broad and permissive language, which allows lawyers and judges to structure their arguments in legal terms, even when these are inherently connected to political issues. Judges, in an attempt to maintain their mantle of neutrality and not appear partisan, have generally been less willing to engage directly with political arguments made by the parties. ${ }^{69}$ Conversely, where such arguments are presented through the lens of human rights, courts have been more prepared to entertain them. ${ }^{70}$ This is partly due to the judiciary's constitutional obligation to uphold human rights, even when this might result in politically controversial outcomes. It is also because of the view that while judges are ill-suited to deal with political arguments ${ }^{71}$ they are particularly well-placed to decide on the interpretation of human rights. ${ }^{72}$ Especially in politically controversial cases, judges have an interest in presenting their judgments as reflections of deeper values and commitments, such as human rights, in order to lend them greater legitimacy and acceptance by the public and political actors that are affected by them. ${ }^{73}$ Finally, the increasing reliance on human rights arguments when resolving politically controversial cases 
is not only a characteristic of the domestic judiciary, but has (more controversially) also been practiced by regional human rights courts. ${ }^{74}$ In turn, the institutional dialogue that takes place between national and international courts fuels the tendency to rely on human rights on the domestic level to an even greater extent. ${ }^{75}$

Nevertheless, while understandable, this increased reliance on human rights can also result in problems with the courts' jurisprudence. The first problem arises from the fact that by adopting a human rights reasoning, it becomes easier for the judiciary to separate the case from the political discussion it forms part of and treat it as only specific to its own facts. This, in turn, can give rise to inconsistent judicial rulings, which can undermine the legitimacy of the court and the judgments it delivers. Illustrative of this are two cases of the South African Constitutional Court, both of which were presented in terms of the right to political participation. On the one hand, in the floor-crossing case discussed in the Introduction, the Court adopted a very narrow interpretation of Section 19 of the Constitution and held that the objective of the right was (just) to safeguard elections and the citizens' participation in political activities. ${ }^{76}$ In-between elections, it reasoned, citizens were powerless to influence the actions of their representatives. Thus, since the practice of floor-crossing did not prevent citizens from becoming involved in the political and electoral processes, it was not unconstitutional and the only remedy available to the applicants was to wait and express their disapproval through the ballot box. $^{77}$

In the second case - Doctors for Life International - the question before the Court was whether the National Council of Provinces (the lower Chamber of Parliament) had an obligation to consult interested parties before it passed legislation. ${ }^{78}$ While the question was a deeply political one and went to the heart of the relationship between the newly formed democratically 
elected legislature and the citizens, ${ }^{79}$ the Court's decision to only rely on human rights arguments in its reasoning portrayed this as merely a legal dilemma. The Court first referred to Section 72(1)(a) of the Constitution which provides that the National Council of Provinces 'must ... facilitate public involvement in [its] legislative and other processes.' Then, it interpreted this provision in light of the right to political participation, by drawing inspiration from the relevant provisions of the International Covenant on Civil and Political Rights and the African Charter on Human and Peoples' Rights. In a vein that resembled nothing of its reasoning in the floor-crossing case, the Court argued that 'it would be a travesty of our Constitution to treat democracy as going into a deep sleep after elections, only to be kissed back to short spells of life every five years. ${ }^{80}$ Consequently, it held that Section 19 could not only be about the organising of free and regular elections; rather, it also entailed an obligation on behalf of the National Council of Provinces to consult with the interested parties before the passing of legislation.

Both the floor-crossing case and Doctors for Life International are concerned with the kind of rules and processes the South African state should adopt in order to promote the democratic ideal it aspires to achieve following apartheid. Yet, instead of seeing them as instances of the same political dilemma and treating them in a consistent manner, the Court viewed them as dealing with two distinct and unrelated human rights questions. ${ }^{81}$ This allowed it to shape the right to political participation on which it was relying - in each case in a different way - in order to reach the outcome that it considered to be the most desirable one. Upon a careful reading of the floor-crossing case, no principled reason is given for why the right to political participation should be interpreted narrowly, rather than in the way that was subsequently preferred in Doctors for Life International. Ultimately, it appears that the Court decided the two cases on what seem to be political grounds, as evidenced by the inconsistent application 
of the law on which it was relying, without however acknowledging that it engaged in such a political exercise. In turn, this risked undermining its legitimacy and did little to promote the acceptance of its decisions in what were already divisive conflicts.

The second problem that arises when courts treat complex political conflicts as 'simple' human rights cases concerns the type of remedy that becomes available to the applicant. Brown and Waller argue that the 'problem' of 'bold courts [...] is not that their tools are weak. Instead, they are powerful but crude; further, they are often wielded in a clumsy manner by justices with an imperfect political sense. ${ }^{82}$ Although the authors do not elaborate on this criticism, an assessment of the use of human rights in order to resolve political conflicts in post-violence societies confirms their point. In particular, because the political conflict and the human rights violation are related, but ultimately the latter is only one instance or consequence of the former, there is a danger that a simple human rights reasoning will achieve either 'too much' or 'too little' ${ }^{83}$

Take for instance the floor-crossing case, which presents an example of the second of the two dangers. Here, the applicant had submitted to the South African Constitutional Court that one implication of allowing a sitting member of Parliament to change political affiliations while keeping his seat in the legislature, was the possible limitation of the right to vote. After all, what are well known are not the positions of the individual politician himself, but rather, those of the party that he is representing. When the politician defects to another party, he stops supporting the positions that made him appealing to the citizenry and got him elected to Parliament in the first place. Thus, allowing him to break the trust of the electorate is cancelling, or even worse, misplacing, the people's vote and violates Section $19 .{ }^{84}$ Whether one agrees with this argument or not, the practice of floor-crossing, just like the political dilemma in the 
Bosnian ethnic voting cases discussed above, has much broader implications than the infringement of a human right. It can also affect the kind of deals that politicians are likely to make behind closed doors in order to prevent or encourage members of Parliament to defect from their party. Moreover, according to the South African law, a Member of Parliament could change political allegiances, only if he was followed by at least $10 \%$ of his party's representatives. ${ }^{85}$ Bearing in mind the fact that at the time the case was heard, the African National Congress had 252 out of the 400 seats in Parliament, floor-crossing could have important implications on the quality of democracy in the country. ${ }^{86}$ In particular, it could result in a one-way traffic from the smaller parties to the ruling one with disastrous consequences for the South African opposition. Of these three implications, the applicant and Court only focused on the first, presumably because it was the only one that could be presented in human rights terms.

Presenting floor-crossing as unconstitutional because it infringed on the right to vote, as the applicants did in South Africa, meant that the only acceptable remedy to a potential violation would be to prohibit the practice altogether. However, had the problem been perceived differently, the solution could have been presented in less absolute terms as well. The danger of members of Parliament engaging in backroom deals could have been addressed through a provision preventing the defector from being granted additional political power in her new party during the first 3-5 years after she crossed the floor. Similarly, if the objection concerned the one-sided flow of (the most talented) politicians from the smaller to the bigger parties, this could also have been addressed in a different way. There could have been, for example, quotas on how many members had to defect together, depending on the size of the party. If the party is a small one, the $10 \%$ quota seems reasonable. However, in case of bigger parties, such as those holding more than $30 \%$ of the seats, a lower, or even no quota, would have been fairer. 
It appears therefore that presenting a politically complex conflict exclusively in human rights terms, runs the risk of achieving too little as it oversimplifies it and restricts the types of remedies and solutions that could have adequately addressed it.

At the same time, there is a danger that using human rights as proxies for political conflicts might also achieve too much. Illustrative of this is Doctors for Life International in which the South African Constitutional Court interpreted the right to political participation as encompassing the right to be consulted before the passing of legislation. It was a small jump from there for the Court to conclude that the right also includes a corollary obligation on behalf of the state to educate the citizenry to such an extent that it can participate in an effective manner in these consultation exercises ${ }^{87}$ Conditions that are conducive to the effective exercise of the right, the Court held, include 'to mention a few [...] road shows, regional workshops, radio programs and publications aimed at educating and informing the public about ways to

influence Parliament' ${ }^{88}$ While however, educating the populace is a desirable objective for every society, it cannot be readily and persuasively inferred from the right to political participation, especially when the South African Constitution protects the right to education, which neither the parties nor the Court made reference to in this case. ${ }^{89}$ Thus, by attempting to achieve a politically satisfactory result, the Court stretched the right which it happened to rely on beyond recognition and arguably imposed, in the process, excessive and unforeseeable obligations on the state. Conversely, a different type of judicial reasoning that does not give rise to such all-or-nothing remedies could provide more nuanced solutions to complex political conflicts. It is to this suggestion that the final section now turns.

\section{Paving a New Way Forward: The Use of Constitutional Guiding Principles}


If demands for the adjudication of political conflicts are here to stay and the current strategy adopted by courts around the world - relying on human rights - suffers from the limitations discussed above, what alternative are they left with? This section argues that when dealing with complex political conflicts, courts should acknowledge them as such and rely for guidance on principles that they derive from their respective constitutions. These constitutional guiding principles can either replace the human rights analysis that courts often resort to, or perhaps more often, inform and enrich the existing human rights arguments by linking them more explicitly to the political conflict at hand. Reliance on such principles, which has already taken place to some extent in practice, has four major advantages over the exclusive use of human rights arguments. First, this type of judicial reasoning can give rise to remedies that provide better-suited solutions to the political conflicts in question. Second, constitutional principles are flexible enough to guide the courts in a range of political conflicts and not only in those cases that can be articulated in human rights terms. Third, since these principles will only be relied on during the adjudication of political conflicts, their use will allow judges to be honest about what it is they are doing, rather than pretend that their decision does not have any political implications, or that these should not be considered. And finally, the more constitutional guiding principles are used and developed by the courts, the more readily they will also provide pre-emptive guidance that will avoid the escalation of political conflicts in the future.

The guiding principles that courts can rely on when adjudicating political conflicts are often laid out in preambles, which 'due to their content, $[\ldots]$ are located at a crossroads between politics and law', or in the first articles of constitutional documents. ${ }^{90}$ For instance, detailed guiding principles are found in the preamble of the Constitution of the Republic of North Macedonia, which declares the intention of 'providing peace and coexistence, social justice, economic well-being and prosperity in the life of the individual and the community', objectives 
that will 'preserve and develop everything that is valuable from the rich cultural inheritance and coexistence within Macedonia'. Similarly, Section 1 of the South African Constitution makes reference to the principles of 'democratic government', 'accountability, responsiveness and openness', while the Declaration of Support in the Belfast Agreement refers to the firm dedication of the parties 'to the achievement of reconciliation, tolerance and mutual trust'. It is these principles, which are related to human rights but are not exhausted by them, that the judiciary should use and be guided by when adjudicating political conflicts.

In cases where the guiding principles form part of the preamble rather than the operative part of the constitution, questions might arise as to whether the judiciary is able to rely on them directly, or if they can merely provide support when judges are interpreting substantive constitutional provisions. ${ }^{91}$ The answer to this depends on the specific wording of each constitution, but over the years there has been an increasing tendency among apex courts around the world to see preambles as more than ceremonial declarations at the beginning of the constitution. ${ }^{92}$ Thus, in instances where constitutional principles are legally binding in their own right, they can be used instead of human rights, ${ }^{93}$ while if they can only provide interpretive guidance, courts can rely on them in conjunction with human rights. ${ }^{94}$ Both approaches have advantages over the sole use of a human rights reasoning, which are discussed in more detail towards the end of this section.

The most obvious stumbling blocks to applying this strategy in practice concern the difficulties of identifying the guiding principles, and the associated danger that this exercise can give courts almost unhinged autonomy. ${ }^{95}$ As the examples in the previous paragraphs suggest, constitutions in post-violence societies refer to a range of principles, the combination of which paints a unique picture of each country's objectives and priorities. Although references to 
principles such as democracy and the rule of law are common, ${ }^{96}$ they are not universal, thus making it impossible to derive a comprehensive list that judges can rely on when adjudicating political conflicts. Nevertheless, the power of the judiciary to identify these principles is not unlimited. In order for judges to use a principle in the manner suggested here, they cannot arbitrarily declare its importance, but must ensure that it has a basis in the text of the constitution they have sworn to uphold and defend.

The exact judicial reasoning or process that will be adopted to identify and interpret specific constitutional principles, changes depending on the court that will be relying on them. In some jurisdictions, the judiciary might settle on a list of principles by extrapolating these from the preamble or main clauses of the constitution; in others, by relying on case law from other countries or international courts and engaging in a transplantation of ideas and legal concepts. A different possibility is for a constitutional principle to become part of the judiciary's toolbox, if judges rely on academic writings that have drawn links between such a principle and human rights, or other key concepts mentioned in the constitution or the peace agreement. Finally, when a court identifies and interprets constitutional principles for the first time, this process might take a life of its own and subsequent principles could emerge through the development of case law. No matter the mechanisms through which these principles will form part of the judiciary's repertoire, as time passes, they will become more entrenched and easier to rely on. ${ }^{97}$ While at the beginning, courts are likely to have significant discretion in their identification and clarification of such principles, this exercise is not substantively different from interpreting human rights in ways their original drafters never envisioned, in an attempt to resolve novel political conflicts. 
A related criticism against the use of guiding principles is that their broadness and flexibility can undermine legal certainty, a problem that can have particularly serious consequences in already unstable contexts, such as post-violence societies. ${ }^{98}$ One way of limiting their use and associated dangers therefore, is for the judiciary to rely on these guiding principles only when resolving disputes relating to 'mega-politics', ${ }^{99}$ what has been referred to here as 'political conflicts', while leaving the more traditional human rights reasoning to simpler cases. A similar suggestion has been made by Choudhry and Howse, who advocate a theory of 'dualist interpretation'. ${ }^{100}$ According to this theory, courts should generally carry out the task of ordinary interpretation of legal texts, but in 'exceptional moments', they should engage in 'extra-ordinary interpretation', a process that would allow them to rely on a set of 'unwritten constitutional norms' and not only the text of the constitution itself. ${ }^{101}$ While promising, the theory of 'dualist interpretation' is discussed briefly and suggested in the context of only one politically controversial case. Conversely, this article proposes the more general use of guiding principles during the adjudication of the most controversial political conflicts.

Further inspiration for the idea of using guiding principles to resolve political conflicts was derived from Issacharoff's and Pildes' argument that the US Supreme Court should engage in 'second order judicial review'. ${ }^{102}$ According to the two authors, first order judicial review, which is what courts usually engage in, is concerned with the adjudication of individual rights. However, in cases that relate to the regulation of democratic politics, such as those dealing with racial and political gerrymandering, human rights reasoning addresses the symptom rather than the cause of the problem. In such instances, Issacharoff and Pildes argue, courts are better off examining the background rules that structure political competition, and interference with which, results in the human rights violation. The authors' suggestion is both more modest and applies to a narrower category of cases than the proposal made here. Second order judicial 
review draws from already existing and accepted legal practices, since it involves a transplantation of such practices from the sphere of private to that of public law, while the use of constitutional guiding principles is a lot more ground-breaking. It requires first, that the judiciary extracts such principles from the constitutional document and then that it either gives legal content to them, or uses them to interpret other legal provisions. At the same time, the 'democratic politics cases' to which Issacharoff and Pildes' second order judicial review applies, include, but do not exhaust, the range of political conflicts that are discussed in this article. While for example, Doctors for Life International would be a 'democratic politics case' falling under the authors' suggestion, questions on ethnic representation in the police service or the use of amnesties by a Truth and Reconciliation Commission would probably not. The two suggestions are similar however, in that they recognise the limitations of the approach currently used by the judiciary and urge judges to adopt new methods to address them.

While this article makes a general argument in favour of reliance on constitutional principles, whether they will or should be used by individual courts in different post-violence societies, depends on a range of factors. These include the selection process for the judges of apex courts, whether they are staffed by international members in addition to the domestic ones, and their wider perceived and real independence. ${ }^{103}$ Simply put, the more legitimate they appear in the eyes of the public and key stakeholders, the more likely are the judges to rely on innovative tools, like constitutional principles. At the same time, the use of such tools will also depend on their acceptance by other institutions in the country, like international mediators involved in the peace process. Most telling in this regard, is the fact that the High Representative in Bosnia and Herzegovina - an international official tasked with the civilian implementation of the peace agreement in the country ${ }^{104}$ - did not oppose the use of constitutional principles in a range of 
cases by the Court, but threatened to take action against judges that used even traditional human rights reasoning to criticise his own decisions. ${ }^{105}$

The suggestion to rely on constitutional guiding principles has already been endorsed by the Canadian Supreme Court in the landmark Reference Re Secession of Quebec case. ${ }^{106}$ While Canada is not a post-violence society, the nature of the question addressed by the Court is similar to the political conflicts that are discussed here, and could therefore provide inspiration for their successful adjudication. At issue in this case was the - inherently political and deeply divisive - disagreement of whether the Province of Quebec had a right to unilaterally secede from the rest of Canada, a question that was presented to the Court as one concerning the interpretation of the right to self-determination. The problem with relying on this right was that at the very heart of the political conflict that the Court was called to resolve was the logically prior question of the identity of the right-holder. If self-determination was a right of the Canadian people, then Quebec would not be able to secede without their consent. If it was the Quebecois that had the right however, a unilateral secession would have been legally possible. Thus, relying on the right to self-determination created the risk that the Court would be predetermining the answer, depending on how it had phrased the question in the first place. Resisting the temptation to revert back to the familiar rights language, the Court relied on four fundamental principles that underlined the Canadian Constitution - federalism; democracy; constitutionalism and the rule of the law; and the protection of minorities. ${ }^{107}$ By interpreting the four principles, the Court reached a more nuanced conclusion than what the dichotomous language of human rights would have allowed. It concluded that a referendum that showed a willingness on behalf of the Quebecois to secede from the rest of the country, did not necessarily grant a right of secession, but it did make it necessary for the state institutions to engage in a serious debate with the Quebecois about the future of Canada. ${ }^{108}$ 
This decision of the Court points to the first advantage of relying on such guiding principles rather than human rights arguments, namely that they can result in a better-suited remedy for the political conflict at hand. Had this been perceived as a 'simple' self-determination case, the Court could have only reached one of two conclusions: either there would have been a violation of the right or there would not. In both cases, the conversation of whether the Quebecois could secede from the rest of the country would have abruptly stopped because the Court would have provided the one definitive 'right' answer and would have excluded the alternative as unconstitutional. Instead, by using these guiding principles, the Court was able to suggest a subtler solution that acknowledged the concerns and demands of both the Quebec Province and the federal government. Rather than stopping the discussion about the legitimacy of a potential Quebecois secession, the case opened the possibilities that were available to the parties even more. This is evidenced by the debates that took place in Parliament and the passing of the Clarity Act 2000, which provided further guidance on the conditions that might lead to the secession of one of the provinces. Thus, far from artificially stopping the political debate with this judgment, 'the Court provided a leadership that had been wanting among political and intellectual elites alike.'109

The second advantage of using guiding principles when adjudicating political conflicts is that they are both flexible and context specific. On the one hand, their broadness and flexibility allow the judiciary to rely on them in a range of conflicts, that are not necessarily restricted to those that somehow relate to an alleged human rights violation. On the other, such principles can be shaped by the judiciary to reflect the particularities of the country in question and therefore, more directly address the political conflict at hand. Constitutional guiding principles are especially likely to reflect the context of the society in question when they are derived from 
the preamble of the constitution, which often includes references to the country's supreme goals and reflects national needs and aspirations. ${ }^{110}$ Conversely, Ginsburg et al argue that constitutional preambles of different countries resemble one another, pointing to a tendency of new constitutions to borrow key terms and phrases from older ones. ${ }^{111}$ While this suggests that constitutional guiding principles are less context specific than originally assumed, the process of interpretation is flavoured by the unique historical experiences of each country and nuances in the original language of every constitution. ${ }^{112}$ As a result of this, even principles that exist in many constitutions around the world are likely to be interpreted differently by distinct apex courts.

This context specificity of constitutional guiding principles allows judges to use them in a range of societies, which differ in terms of the causes, intensity and consequences of the violence they experienced, and by shaping them accordingly, result in responses that are well-suited to different contexts. ${ }^{113}$ Take for instance, the principle of democracy that features in many countries' constitutions. The South African Constitutional Court has held, in light of the country's history and aspirations, that this principle means 'participatory democracy', which entails the active involvement of citizens in the legislative process. ${ }^{114}$ Conversely, the Bosnian Constitutional Court has interpreted 'democracy' in entirely different terms, as a system of governance that is primarily concerned with ensuring the representation of ethnic groups in the decision-making of the country. ${ }^{115}$ Different from both of these procedural accounts, is the position that was adopted by the Canadian Supreme Court, which viewed 'democracy [as] fundamentally connected to substantive goals, most importantly, the promotion of selfgovernment'. ${ }^{116}$ Thus, unlike human rights with their more universalist tendencies, constitutional guiding principles can be shaped to reflect, and respond to, the context of the post-violence society they are applied in. ${ }^{117}$ 
While the first two arguments pointed to the advantages of relying on constitutional guiding principles instead of human rights, the remaining two give reasons why their use by the judiciary to complement human rights would also be beneficial. This is firstly, because relying on these principles liberates judges and allows them to be honest about the political nature of the case, rather than forcing them to pretend that they are dealing with a question that only has legal implications. As Anthony and Morison put it, especially in post-violence societies, judges adjudicating political conflicts have to perform 'a different role than the essentially technical task of deciding disputes. ${ }^{118}$ Acting as if this exercise is identical to the judiciary’s traditional duties serves no one. In fact, presenting the judges - especially if they are members of a constitutional court - as being unaware of or unaffected by the general political climate in the country is both disingenuous and disrespectful of other members of the society. Admitting that courts are conscious of the political implications of their decisions does not undermine their neutrality or legitimacy in any way. ${ }^{119}$ To the contrary, an honest judicial approach that treats a political question in these terms, rather than camouflaging it as a legal one, is likely to be perceived as more legitimate because the arguments used by the court will be genuine and more relevant to the real issues at hand.

Moreover, few people would be happy to discover that a court which reaches decisions with major implications for the polity at large, is 'a political, economic and social eunuch'. ${ }^{120}$ Awareness of and concern about the wider implications of their decisions do not make judges mere 'politicians in robes'; ${ }^{121}$ after all, they still need to deliberate and persuasively interpret the relevant legal texts and authorities. ${ }^{122}$ The difference between this exercise when they are using human rights and when they are relying on guiding principles is that in the latter case, the judiciary's reasoning is more transparent. The social benefits in delivering transparent 
judgments and establishing a communication between law makers and the public have been recognised since Plato, who argued that laws should be preceded by preambles that persuade the people to comply with their legal obligations, not because of civil or criminal sanctions, but because these are morally just. ${ }^{123}$ Being honest about the specific political dilemmas that arise in each case and relying on constitutional guiding principles in order to resolve them in a coherent manner, seeks to achieve precisely this objective.

The increased clarity in judicial reasoning when adjudicating political conflicts points to the final advantage of relying on constitutional guiding principles, namely that over time, their continuous interpretation can provide pre-emptive guidance about how political conflicts should be resolved. In turn, this can encourage the politicians themselves to deal with disputes in a more principled manner before they escalate, and therefore avoid as much as possible the need for the judiciary to become involved in the resolution of the political conflict at a later stage. Such pre-emptive guidance was, for example, given by the Bosnian Constitutional Court when dealing with the use of the veto power in the legislature. ${ }^{124}$ In the first such case to reach the Court, the judges started from the premise that using the veto power in the Parliamentary Assembly should be

guided by the values and principles essential for a free and democratic society which embodies, inter alia, respect for the inherent dignity of the man, great diversity of beliefs, respect for cultural identity and identity of the groups as well as the trust in the social and political institutions which promote participation of individuals and groups in society. ${ }^{125}$

Developing this, the Court reasoned that the use of the veto power should strike a balance between two possibly conflicting considerations, the need to protect the 'vital interests' of the 
ethnic groups on the one hand, and ensuring 'state functionality' on the other. ${ }^{126}$ Then, relying on this balancing exercise, it went on to give examples of legitimate uses of the veto power, such as when groups are trying to ensure their effective participation in government or protect their language and religion. ${ }^{127}$ By providing detailed guidance in the first veto case, the Court contributed, as much as it could, to the avoidance of inappropriate uses of the veto power by politicians in the future and limited its after-the-event intervention.

The Bosnian Constitutional Court used a similar strategy of providing pre-emptive guidance when developing the meaning of the principle of 'a multi-ethnic state'. This was first discussed in the Constituent Peoples case, which was concerned, among others, with whether ethnic quotas could be used in state institutions. ${ }^{128}$ The Court resolved this conflict by citing Reference re Secession of Quebec and starting from the premise that the Constitution includes '[b]asic constitutional principles and goals for the functioning of Bosnia and Herzegovina which must be viewed as constitutional guidelines'. ${ }^{129}$ These guidelines - 'pluralism, fair procedures, peaceful relations following from the text of the Constitution' - helped the judges give substance to the label of a 'multi-ethnic state'. ${ }^{130}$ The 'multi-ethnic state', the Court continued, must produce 'peaceful relations within a pluralist society', ${ }^{131}$ which could only be achieved by relying on 'ethnic structures' (in other words, quotas). ${ }^{132}$ This interpretation of the Constitution suggested that it was not only necessary to ensure the effective participation in government of individuals that were members of specific groups, but also, to protect the ethnic groups as such by safeguarding their collective rights. ${ }^{133}$ Over time, and as the Court continued relying on this reading of the preamble, its once controversial interpretation of the Bosnian 'multi-ethnic state' has become increasingly accepted. ${ }^{134}$ For example, this guiding principle was successfully used to resolve the divisive conflict of whether there should be guaranteed representation of the three main ethnic groups at the municipal (and not only state and federal) 
level. ${ }^{135}$ Thus, the consistent use of guiding principles by the judiciary can diffuse volatile situations and avoid the escalation of the conflicts by sending the message that they will be resolved through a familiar strategy that will not rock the political boat.

\section{E. Conclusion}

The objective of this article has not been to suggest that courts should necessarily become involved in the resolution of political conflicts. Whether they will, depends on the extent to which they have been empowered to do so by the constitution itself and by the legal culture in their respective countries. ${ }^{136}$ However, as a matter of fact, courts in post-violence societies around the world have adjudicated political conflicts and acted as agents of change in the process. This is primarily because the context in which they operate, both in terms of what is happening on the ground and the legal changes that have been implemented as a result, provides ample opportunities for, and sometimes even necessitates, judicial activism. While decisions of the courts when resolving political conflicts have often relied on a human rights reasoning, it has been argued here that such a temptation should be avoided. This reliance can produce inconsistent and contradictory case law, while at the same time lead to remedies that are illsuited for the political conflict the court was called to address. Since the demand for courts to adjudicate and resolve such disputes is unlikely to dissipate, this leaves the judiciary in an awkward middle space: expected to deal with political conflicts on the one hand, but without the appropriate tools to do so, on the other.

One way of addressing this gap in the judiciary's toolbox is for the judges to give legal content to, interpret and rely on guiding principles that they extract from their countries' constitutions. Such use of constitutional guiding principles has already been attempted by judges, albeit rather sporadically. Drawing on these experiences, the article has argued that the use of guiding 
principles can increase the judgments' transparency and improve the types of remedies ordered by the courts. Moreover, if they are used consistently, these principles can provide guidance to the political players as to the best way to resolve the conflict, thus preemptively preventing the stagnation of the political process and the judiciary's intervention. These conclusions are not only of theoretical importance. They are intended to urge both the parties and judges to consider the use of guiding principles and encourage the transplantation of successful practices from one post-violence society to the other. At the same time, this analysis is relevant to the drafting processes of peace agreements and new constitutions, since it suggests that the inclusion of guiding principles in these documents could make them more dynamic and empower the postviolence society's institutions to respond to ongoing political conflicts more effectively.

${ }^{1}$ United Democratic Front $v$ President of the Republic of South Africa et al CCT 23/02 (4 October 2002) (South African Constitutional Court).

${ }^{2}$ Ibid., [11].

3 Ran Hirschl, Towards Juristocracy: The Origins and Consequences of the New Constitutionalism (Cambridge, Mass.: Harvard University Press, 2004).

${ }^{4}$ Stephen Tierney, Constitutional Law and National Pluralism (Oxford: Oxford University Press, 2004).

5 Richard Pildes and Samuel Issacharoff, 'Politics as Markets: Partisan Lockups of the Democratic Process' Stanford Law Review 50: 643-717 (1998).

6 John Ferejohn, 'Judicializing Politics, Politicizing Law' (2002) 65 Law and Contemporary Problems 65: 41-68 (2002).

7 David Feldman, 'Renaming Cities in Bosnia and Herzegovina' International Journal of Constitutional Law 3(4): 649-662 (2005).

${ }^{8}$ Gordon Anthony and John Morison, 'The Judicial Role in the New Northern Ireland: Constitutional Litigation and Transition' European Review of Public Law 21(3): 1219-1240 (2009).

${ }^{9}$ For a more detailed definition and typology of conflicts in post-violence societies, see Nasia Hadjigeorgiou, Protecting Human Rights and Building Peace in Post-violence Societies (Oxford: Hart Publishing, 2020), 81-83. For a deeper exploration of what we mean by political conflicts more generally, see Ran Hirschl, 'The Judicialization of Mega-Politics and the Rise of Political Courts' Annual Review of Political Science 11: 93-118 (2008); David Robertson, The Judge as Political Theorist: Contemporary Constitutional Review (Princeton N.J: Princeton University Press, 2010), 19-20.

${ }^{10}$ Donald Horowitz, Ethnic Groups in Conflict (Berkeley: University of California Press, 1985, $2^{\text {nd }}$ ed.). 
${ }^{11}$ For a critique of the more extensive use of unwritten constitutional principles in Canada, see Jean Leclair, 'Canada's Unfathomable Unwritten Constitutional Principles' Queen's Law Journal 27: 389-443 (2001-2002).

${ }^{12}$ Lon Fuller 'The Forms and Limits of Adjudication' Harvard Law Review 92: 353-409 (197879).

${ }^{13}$ Lia Nijzink and Jessica Piombo, 'Parliament and the Electoral System: How are South Africans Being Represented?' in Jessica Piombo and Lia Nijzink, Electoral Politics in South Africa: Assessing the First Democratic Decade' (New York; Basingstoke: Palgrave Macmillan, 2005).

${ }^{14}$ Ruti Teitel, 'Transitional Jurisprudence: The Role of Law in Political Transformation' Yale Law Journal 106: 2009-80 (1997); Samuel Issacharoff, Fragile Democracies: Contested Power in the Era of Constitutional Courts (Cambridge: Cambridge University Press, 2015).

15 John Paul Lederach, Preparing for Peace: Conflict Transformation Across Cultures (Syracuse, N.Y.: Syracuse University Press, 1995), 17.

16 Peter Harris and Ben Reilly, 'Democracy and Deep-Rooted Conflict: Options for Negotiators' (Stockholm: International Institute for Democracy and Electoral Assistance, 1998), 17-18.

${ }^{17}$ Hadjigeorgiou, Protecting Human Rights and Building Peace in Post-violence Societies, 6275.

18 John D. Brewer, Peace Processes: A Sociological Approach (Cambridge: Polity Press, 2010), 17.

${ }^{19}$ International Crisis Group, 'Bosnia's Future' (Europe Report No 232, 10 July 2014), 1.

${ }^{20}$ David Welsh, The Rise and Fall of Apartheid (Charlottesville: University of Virginia Press, 2009), 535.

${ }^{21}$ Her Majesty's Inspectorate of Constabulary, 'Inspection of the Police Service of Northern Ireland Historical Enquiries Team' (2013), 6.

${ }^{22}$ Sujit Choudhry, 'Bridging Comparative Politics and Comparative Constitutional Law: Constitutional Design in Divided Societies' in Sujit Choudhry (ed.), Constitutional Design for Divided Societies: Integration or Accommodation? (Oxford: Oxford University Press, 2008), 3-40.

${ }^{23}$ Ruti Teitel, Transitional Justice (Oxford: Oxford University Press, 2000), 27.

${ }^{24}$ U-5/98 ( ${ }^{\text {rd }}$ Partial Opinion) of 1 July 2000 (Bosnian Constitutional Court).

${ }^{25}$ Azanian Peoples Organization and Others v. President of the Republic of South Africa CCT 17/96 [1996] ZACC 16 (25 July 1996, South African Constitutional Court).

${ }^{26}$ Robinson v. Secretary of State for Northern Ireland [2002] UKHL 32 (UK House of Lords). On the political nature of this judgment, see Jenna Sapiano, 'Courting Peace: Judicial Review and Peace Jurisprudence’ (2017) Global Constitutionalism 6(1): 131-165 (2017).

${ }^{27}$ Samuel Issacharoff, 'Democracy and Collective Decision Making' International Journal of Constitutional Law 6: 231-266 (2008), 266.

${ }^{28}$ There is very rich literature on the democratic legitimacy, or otherwise, of Courts engaging in judicial review. For representative examples, see Richard Bellamy, 'The Democratic Qualities of Courts: A Critical Analysis of Three Arguments' Representation 49(3): 333-346 (2013); Michel Troper, 'The Logic of Justification of Judicial Review' International Journal of Constitutional Law 1(1): 99-121 (2003); Luc B. Tremblay, 'The Legitimacy of Judicial Review: The Limits of Dialogue Between Courts and Legislatures' International Journal of Constitutional Law 3(4): 617-648 (2005); Jeremy Waldron, 'Judges as Moral Reasoners' International Journal of Constitutional Law 7(1): 2-24 (2009). Much has also been written on the role and effect of apex courts when engaging in judicial review in federal states. See, for instance, Patricia Popelier, 'Federalism Disputes and the Behavior of Courts: Explaining Variation in Federal Courts' Support for Centralization' Publius: The Journal of Federalism 
47(1): 27-48 (2017); André Bzdera, 'Comparative Analysis of Federal High Courts: A Political Theory of Judicial Review' Canadian Journal of Political Science/Revue Canadienne de Science Politique 26(1): 3-29 (1993). Finally, there have been decades-long debates about the approach that courts should adopt when interpreting the constitution, namely whether they should be relying on the original understanding of the text, or treating it as a living instrument. For an excellent and recent overview of the literature on this, see Lawrence B. Solum, 'Originalism versus Living Constitutionalism: The Conceptual Structure of the Great Debate' Northwestern University Law Review 113(6): 1243-1296 (2019).

This article builds on this literature but does not seek to offer an exhaustive (or even basic) description of it.

${ }^{29}$ Since the phenomenon of increased adjudication of political conflicts does not only occur in post-violence societies, explanations for its increasing popularity merit further research on a broader scale. This, however, is outside the scope of the article.

${ }^{30}$ Robertson, The Judge as Political Theorist, 28.

${ }^{31}$ Carlo Guarnieri et al, The Power of Judges: A Comparative Case Study of Courts and Democracy (Oxford: Oxford University Press, 2002), 160-181. For an illustration of this in Bosnia and Herzegovina, see Asim Mujkic, 'We, the Citizens of Ethnopolis' Constellations 14: 112-128 (2007).

${ }^{32}$ Ferejohn, 'Judicializing Politics, Politicizing Law', 55; Nathan J. Brown and Julian G. Waller, 'Constitutional Courts and Political Uncertainty: Constitutional Ruptures and the Rule of Judges' International Journal of Constitutional Law 14(4): 817-850 (2016).

33 Özalp Behiç v. Republic of Cyprus (2008) 4 A.A.A. 355 (29 May 2008, Republic of Cyprus Supreme Court).

${ }^{34}$ Republic of Cyprus v. Vasos Vasiliou (Civil Appeal No. 381/2010) (26 May 2015, Republic of Cyprus Court of Civil Appeals).

35 Jurisdictions that have, over the years, adopted consociational arrangements include Belgium, the Netherlands, Switzerland, South Tyrol, Cyprus, Bosnia and Herzegovina, the Former Yugoslav Republic of Macedonia, Northern Ireland, Lebanon, Netherlands Antilles, South Africa (between 1993-1996), Iraq and India. (Christopher McCrudden and Brendan O'Leary, 'Courts and Consociations, or How Human Rights Courts May De-stabilise Powersharing Settlements' European Journal of International Law 24(2): 477-501 (2013), 480.)

${ }^{36}$ Arendt Lijphart, Democracy in Plural Societies: A Comparative Exploration (New Haven: Yale University Press, 1977).

37 David Wippman, 'Practical and Legal Constraints on Internal Power Sharing' in David Wippman (ed.), International Law and Ethnic Conflict (Ithaca and London: Cornell University Press, 1998), 211-41.

${ }^{38}$ Richard Pildes, 'Ethnic Identity and Democratic Institutions: A Dynamic Perspective' in Sujit Choudhry (ed.), Constitutional Design for Divided Societies: Integration or Accommodation? (Oxford: Oxford University Press, 2008), 173-201.

${ }^{39}$ Decision U-2/04 of 28 May 2004 (Bosnian Constitutional Court), [27].

${ }^{40}$ For additional information on the adoption of the South African Constitution, see p. 8 above.

${ }^{41}$ The Bosnian Constitution is Annex 4 of the General Framework Agreement for Peace in Bosnia and Herzegovina signed in Paris on 14 December 1995.

${ }^{42}$ Northern Ireland Act 1998, Introductory Text.

${ }^{43}$ Robinson v. Secretary of State for Northern Ireland, [11].

${ }^{44}$ A similar provision was included in the Annan Plan, a negotiated agreement for the reunification of Cyprus that was put to a referendum, and rejected by the majority of Cypriots. (Plan for the Comprehensive Settlement of the Cyprus Problem (31 March 2004), [6(3)].)

${ }^{45}$ Decision U-10/05 of 22 July 2005 (Bosnian Constitutional Court).

${ }^{46}$ Decision U-8/04 of 25 June 2004 (Bosnian Constitutional Court). 
${ }^{47}$ Certification of the Constitution of the Republic of South Africa CCT 23/96 (6 September 1996, South African Constitutional Court), [13].

${ }^{48}$ Ibid.

49 Certification of the Amended Text of the Constitution of the Republic of South Africa CCT37/96 (4 December 1996, South African Constitutional Court).

${ }^{50}$ Neophytos Loizides, Designing Peace: Cyprus and Institutional Innovations in Divided Societies (Philadelphia: University of Pennsylvania Press, 2015), 145-148.

51 Official website of Constitutional Court of South Africa, http://www.constitutionalcourt.org.za/site/thecourt/history.htm.

${ }^{52}$ Constitution of East Timor 2002, Article 124.

${ }^{53}$ The Annan Plan, Article 36(7).

${ }^{54}$ Donald L. Horowitz, 'Constitutional Courts: A Primer for Decision Makers' Journal of Democracy 17(4): 125-37 (2006), 125.

${ }^{55}$ Victor Ferreres, 'The Consequences of Centralizing Constitutional Review in a Special

Court: Some Thoughts on Judicial Activism' Texas Law Review 82: 1705-1736 (2003-2004).

${ }^{56}$ Sujit Chouldhry, 'After the Rights Revolution: Bill of Rights in the Postconflict State' Annual Review of Law and Social Science 6: 301-22 (2010).

${ }^{57}$ Constitution of Bosnia and Herzegovina, Annex 1.

${ }^{58}$ Final Constitution of the Republic of South Africa 1996, Chapter 2.

${ }^{59}$ Issacharoff, 'Democracy and Collective Decision Making', 253.

${ }^{60}$ In Re Parsons Application for Judicial Review (2002) NIQB 46 (Northern Ireland Court of Appeal).

${ }^{61}$ Colin Harvey, 'Contextualised Equality and the Politics of Legal Mobilisation: Affirmative Action in Northern Ireland' Social \& Legal Studies 21(1): 23-50 (2012).

62 For an argument that the existence of both political and judicial conflict-settlement mechanisms is more likely to result in successful transitions, see Ulrich Schneckener 'Making Power-Sharing Work: Lessons from Successes and Failures in Ethnic Conflict Regulation' Journal of Peace Research 39: 203-412 (2002).

${ }^{63}$ Northern Ireland (Sentences) Act 1998, Section 3(8).

${ }^{64}$ Re Williamson's Application for Judicial Review [2000] NI 281 (Northern Ireland Court of Appeal). For a discussion of the political background and implications of this case, see Marie Smyth, "The Human Consequences of Armed Conflict: Constructing "Victimhood" in the Context of Northern Ireland's Troubles' in Michael Cox, Adrian Guelke and Fiona Stephen, A Farewell to Arms? From 'Long War' to Long Peace in Northern Ireland (Manchester: Manchester University Press, 2006), 118-35.

${ }^{65}$ See Issacharoff, Fragile Democracies, 213 arguing that ' $[\mathrm{t}]$ he persistence of the political questions before these courts is striking, even when the courts try to adjudicate the cases in the more familiar posture of individual rights claims.'

${ }^{66}$ Decision U-5/04 of 27 January 2006 (Bosnian Constitutional Court); Decision U-13/05 of 29 September 2006 (Bosnian Constitutional Court); Decision AP-2678/06 of 26 May 2006 (Bosnian Constitutional Court).

${ }^{67}$ Sejdić and Finci v. Bosnia and Herzegovina (2009) 28 B.H.R.C. 201; Pilav v. Bosnia and Hezegovina (App no 41939/07 (ECtHR, 9 June 2016).

${ }^{68}$ Christopher McCrudden and Brendan O'Leary, Courts and Consociations: Human Rights versus Power-Sharing (Oxford: Oxford University Press, 2013).

${ }^{69}$ John Morison and Marie Lynch, 'Litigating the Agreement: Towards a New Judicial Constitutionalism for the UK from Northern Ireland' in John Morison, Kieran McEvoy and Gordon Anthony, Judges, Transition and Human Rights (Oxford: Oxford University Press, 2007), 105-143, 136.

70 Tierney, Constitutional Law and National Pluralism, 247. 
${ }^{71}$ Jeremy Waldron, 'Judges as Moral Reasoners'.

72 Joseph Raz, The Morality of Freedom (Oxford: Oxford University Press, 1986), 259-262.

${ }^{73}$ For a detailed illustration of this practice by the South African Constitutional Court, see Theunis Roux, The Politics of Principle: The First South African Constitutional Court, 19952005 (Cambridge: Cambridge University Press, 2013), 238-248. For an analysis of how essentially political disputes were fought out in an inappropriate legal context in Northern Ireland, 'not least because of the moral punch that human rights and legal rhetoric can deliver', see Christopher McCrudden, 'Consociationalism, Equality and Minorities in the Northern Ireland Bill of Rights Debate: The Role of the OSCE High Commissioner on National Minorities', in John Morison, Kieran McEvoy and Gordon Anthony (eds.), Judges, Transition and Human Rights (Oxford: Oxford University Press, 2007), 315-54, 353.

${ }^{74}$ Tom G. Daly, 'The End of Law's Ambition: Human Rights Courts, Democratisation and Social Justice' iCourts Working Paper Series, No. 67, 2016.

${ }^{75}$ Open Society Justice Initiative, 'From Rights to Remedies: Structures and Strategies for Implementing International Human Rights Decisions' (New York: Open Society Foundation, 2013), 76, noting that 'national judges are also the conduits through which international judgments become effective in national legal orders.'

${ }^{76}$ United Democratic Front, [49].

${ }^{77}$ Ibid.

${ }^{78}$ Doctors for Life International v. The Speaker of the National Assembly CCT 12/05 (17 August 2006, South African Constitutional Court).

${ }^{79}$ The Court expressly linked the question it was asked to answer with the transition process in the country, thus making this case a 'political conflict', when it stated that ' $[\mathrm{t}]$ he nature of our democracy must be understood in the context of our history. As has been observed, during the struggle against apartheid, a system that denied the majority of the people a say in the making of the laws which governed them, the people developed the concept of the people's power as an alternative to the undemocratic system of apartheid. This concept ensured that the people took part in community structures that were set up to fight the system of apartheid.' (Ibid., [112].)

${ }^{80}$ Ibid., [230].

${ }^{81}$ Theunis Roux, 'The Principle of Democracy in South African Constitutional Law' in Stu Woolman and Michael Bishop (eds) Constitutional Conversations (Pretoria: Pretoria University Law Press, 2008), 86.

${ }^{82}$ Brown and Waller, 'Constitutional Courts and Political Uncertainty', 821.

${ }^{83}$ For an illustration of this problem in the US context, see Issacharoff and Pildes, 'Politics as Markets'.

${ }^{84}$ United Democratic Front, [48].

${ }^{85}$ Ibid, [4].

${ }^{86}$ Ibid, [46].

${ }^{87}$ Doctors for Life International, [131].

${ }^{88}$ Ibid., [132].

${ }^{89}$ Constitution of Republic of South Africa, Section 29.

90 Justin O. Frosini, Constitutional Preambles at a Crossroads between Politics and Law (Maggioli Editore, 2012), 21.

91 Liav Orgad, 'The Preamble in Constitutional Interpretation' International Journal of Constitutional Law 8(4): 714-738 (2010).

${ }^{92}$ Frosini, Constitutional Preambles.

${ }^{93}$ An example of a Constitution that allows for this possibility is the Constitution of Turkey, which provides in Article 176 that 'The Preamble, which states the basic views and principles underlying the Constitution, shall form an integral part of the Constitution.' 
${ }^{94}$ For instance, Section 39(1) of the South African Constitution states that 'When interpreting the Bill of Rights, a court, tribunal or forum [...] must promote the values that underlie an open and democratic society based on human dignity, equality and freedom'. The importance of these constitutional guiding principles is reiterated in Section 1 which describes South Africa as one, sovereign, democratic state founded on these values. Despite the power of the Constitutional Court to rely on these principles when adjudicating political conflicts, it has only used them to a limited degree.

${ }^{95}$ Leclair, 'Canada's Unfathomable Unwritten Constitutional Principles', 410.

96 Tom Ginsburg, Nick Foti and Daniel Rockmore, "We the Peoples": The Global Origins of Constitutional Preambles' George Washington International Law Review 46: 101-135 (2014), 120.

${ }^{97}$ For a description of this process, see the discussion accompanying endnotes 124-134.

${ }^{98}$ For a summary of and response to these arguments, see Decision U-5/98 (3 ${ }^{\text {rd }}$ Partial Opinion) of 1 July 2000, at [11] and [17]-[25]. See also Leclair, 'Canada's Unfathomable Unwritten Constitutional Principles'.

99 Ran Hirschl, 'The Fuzzy Boundaries of (Un)Constitutionality: Two Tales of Political Jurisprudence' University of Queensland Law Journal 31: 319-27 (2012), 319.

100 Sujit Choudhry and Robert Howse, 'Constitutional Theory and the Quebec Secession Reference' Canadian Journal of Law and Jurisprudence 13: 143-169 (2000).

${ }^{101}$ Ibid., 156.

102 Issacharoff and Pildes, 'Politics as Markets'.

103 On the selection process of judges in post-violence societies, see Sujit Choudhry and Richard Stacey, 'Independent or Dependent? Constitutional Courts in Divided Societies' in Colin Harvey and Alex Schwartz (eds), Rights in Divided Societies (Oxford: Hart Publishing, 2012), 87-121. On foreign judges in constitutional courts, see Rosalind Dixon and Vicki Jackson, 'Hybrid Constitutional Courts: Foreign Judges on National Constitutional Courts' Columbia Journal of Transnational Law 57: 283-365 (2019).

${ }^{104}$ General Framework Agreement for Peace in Bosnia and Herzegovina signed in Paris on 14 December 1995, Annex 10. For a critical analysis of the work of the Office of the High Representative, see Roland Kostić, 'Shadow Peacebuilders and Diplomatic Counterinsurgencies: Informal Networks, Knowledge Production and the Art of PolicyShaping' Journal of Intervention and Statebuilding 11(1): 120-139 (2017).

105 Office of the High Representative, 'Order on the Implementation of the Decision of the Constitutional Court of Bosnia and Herzegovina in the Appeal of Milorad Bilbija et al, No AP953/05' Doc 37/07 (Sarajevo, Office of the High Representative, 23 March 2007).

${ }^{106}$ Reference Re Secession of Quebec [1998] 2 SCR 217 (Supreme Court of Canada).

${ }^{107}$ Ibid., [49].

${ }^{108}$ Ibid., [92].

109 Tierney, Constitutional Law and National Pluralism, 282.

110 Orgad, 'The Preamble in Constitutional Interpretation' (listing the reference to supreme goals as one of the common characteristics of constitutional preambles); Vicki C. Jackson, 'Methodological Challenges in Comparative Constitutional Law' Penn State International Law Review 28: 319-326 (2010) (describing expressions of national identity in the preambles of several countries.)

${ }^{111}$ Ginsubrg, Foti and Rockmore, "We the Peoples".

112 Ibid., 120.

${ }^{113}$ The idea that constitutional guiding principles should be interpreted in light of the historical context of a country was adopted by the Supreme Court of Canada in Reference Re Secession of Quebec, [32]. 
${ }^{114}$ Doctors for Life International. For an excellent analysis of how the principle of democracy is understood in South Africa, see Theunis Roux, 'Democracy' in Stu Woolman et al (eds) Constitutional Law of South Africa (Durban: Juta \& Co, 2nd ed, 2006), 10-1 - 10-69.

${ }^{115} U-5 / 98$.

${ }^{116}$ Reference Re Secession of Quebec, [64].

117 Makau W. Mutua, 'The Transformation of Africa: A Critique of Rights in Transitional Justice' in Ruth Buchanan and Peer Zumbansen, Law in Transition: Human Rights, Development and Transitional Justice (Oxford: Hart Publishing, 2016), 92.

${ }^{118}$ Anthony and Morison, 'The Judicial Role in the New Northern Ireland', 1239.

${ }^{119}$ Illustrative of this is the fact that the US Supreme Court is popularly perceived as being influenced by the political and ideological views of its members, without this detracting from its legitimacy. (Barry Friedman, 'Mediated Popular Constitutionalism' Michigan Law Review 101: 2595-632 (2003).)

${ }^{120}$ John Griffith, The Politics of the Judiciary (London: Fontana Press, $5^{\text {th }}$ ed, 1997), 290.

${ }^{121}$ James Gibson and Gregory Caldeira, 'Has Legal Realism Damaged the Legitimacy of the US Supreme Court?' Law and Society Review 45(1): 195-219 (2011), 214.

${ }^{122}$ Robertson, The Judge as Political Theorist, 21.

${ }^{123}$ Plato, The Laws (Trevor J. Saunders trans.) (London: Penguin, 2004).

${ }^{124}$ See Constitution of Bosnia and Herzegovina, Article IV(3)(f).

${ }^{125}$ Decision U-2/04 of 28 May 2004 (Bosnian Constitutional Court), [31].

126 Ibid.

${ }^{127}$ Ibid., [34].

${ }^{128}$ Decision U-5/98 ( $3^{\text {rd }}$ Partial Opinion) of 1 July 2000 (Bosnian Constitutional Court).

${ }^{129} U-5 / 98,[24]$.

${ }^{130}$ Ibid., [54].

${ }^{131}$ Constitution of Bosnia and Herzegovina, Preamble.

${ }^{132} U-5 / 98,[54]$.

${ }^{133}$ Ibid., [56].

${ }^{134}$ Anna Mansfield, 'Ethnic but Equal: The Quest for a New Democratic order in Bosnia and Herzegovina’ Columbia Law Review 103(8): 2052-2093 (2003).

${ }^{135}$ U-4/05 of 22 April 2005 (Bosnian Constitutional Court).

${ }^{136}$ Karl Klare, 'Legal Culture and Transformative Constitutionalism' South African Journal on Human Rights 14: 146-88 (1998). 